\title{
American lady, American painted lady, Vanessa virginiensis (Drury) (Insecta: Lepidoptera: Nymphalidae: Nymphalinae) ${ }^{1}$
}

Donald W. Hall ${ }^{2}$

\section{Introduction}

Vanessa virginiensis (Drury) has been known by a number of common names (Cech and Tudor 2005, Miller 1992) including American lady, American painted lady, painted beauty, and Hunter's butterfly. It will be referred to here as the American lady in accord with the Checklist of North American Butterflies Occurring North of Mexico (NABA 2004). Although the adult American lady is an attractive butterfly, it is probably best known among naturalists for the characteristic nests made by its caterpillars.

\section{Distribution}

The American lady occurs from southern Canada throughout the U.S. and southward to northern South America and is seen occasionally in Europe, Hawaii, and the larger Caribbean islands (Scott 1986, Opler and Krizek 1984, Cech and Tudor 2005).

\section{Description}

Adults: The wing spread of adults is 1.75 to 2.40 inches (Daniels 2003). The upper surface of the wings is orange-brown with black margins. The front wings have white spots on the outer third. The lower side of the front wings has a bright pink area. Part of the forewing margin is concave - one of the characteristics that distinguishes it from the similar and closely related painted lady, Vanessa cardui (Linnaeus). The lower side of the hind wing has a characteristic "cob-web" pattern and two large eye spots near the margin. By contrast, the painted lady has a row of four smaller eye spots.

There are two seasonal forms of the adults. The early season form is larger and more brightly colored while the late season form is smaller and is paler in color with reduced black markings (Opler and Krizek 1984).

Eggs: The eggs are yellow-green (Opler and Krizek 1984).

\footnotetext{
1. This document is EENY-449, one of a series of Featured Creatures from the Entomology and Nematology Department, Florida Cooperative Extension Service, Institute of Food and Agricultural Sciences, University of Florida. Published: June 2009. This document is also available on Featured Creatures Web site at http://creatures.ifas.ufl.edu. Please visit the EDIS Web site at http://edis.ifas.ufl.edu. Additional information on these organisms, including many color photographs, is available at the Entomology and Nematology Department website at http://entnemdept.ifas.ufl.edu/

2. Donald W. Hall, professor, Department of Entomology and Nematology; Florida Cooperative Extension Service, Institute of Food and Agricultural Sciences, University of Florida, Gainesville, FL 32611.
}

The Institute of Food and Agricultural Sciences (IFAS) is an Equal Opportunity Institution authorized to provide research, educational information and other services only to individuals and institutions that function with non-discrimination with respect to race, creed, color, religion, age, disability, sex, sexual orientation, marital status, national origin, political opinions or affiliations. U.S. Department of Agriculture, Cooperative Extension Service, University of Florida, IFAS, Florida A. \& M. University Cooperative Extension Program, and Boards of County Commissioners Cooperating. Millie Ferrer, Interim Dean. 


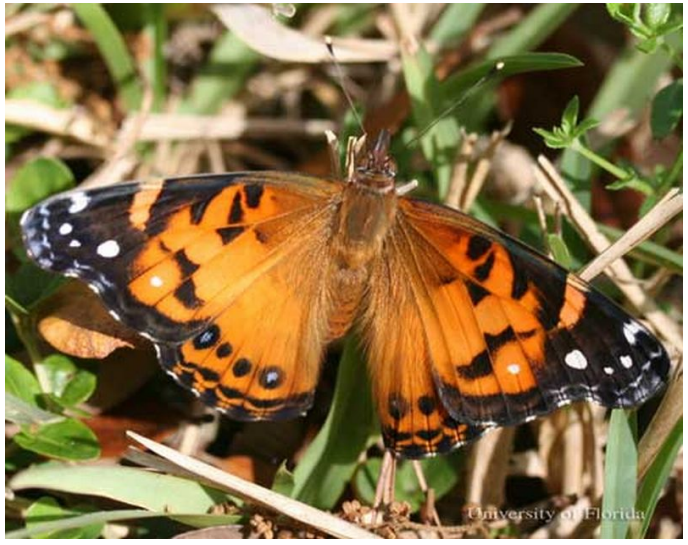

Figure 1. Adult American lady, Vanessa virginiensis (Drury), with dorsal view of wings. Credits: Don Hall, University of Florida

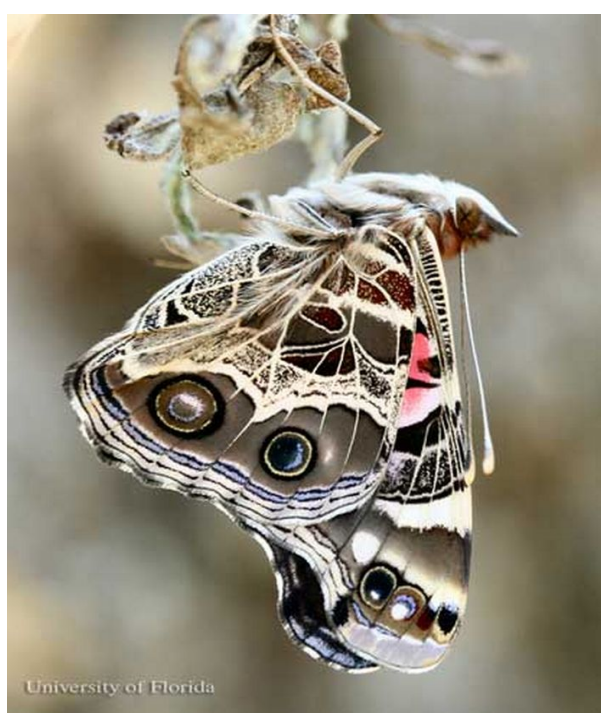

Figure 2. Adult American lady, Vanessa virginiensis (Drury), with ventral view of wings. Credits: Don Hall, University of Florida

Larvae: Full grown larvae are approximately 1.4 inches in length (Minno et al. 2005). The body color is variable. Some larvae are primarily yellow with thin black transverse lines on the anterior and posterior margins of the segments and a narrow transverse black band in the middle of each segment. In some larvae, the median black band is much wider so that the larvae appear to be black with narrow yellow lines. There is a transverse row of large branched spines (scoli) with orange or red bases on each body segment, Abdominal segments two through eight typically have a conspicuous white spot on each side and there is usually a creamy white lateral line that runs most of the length of the body.

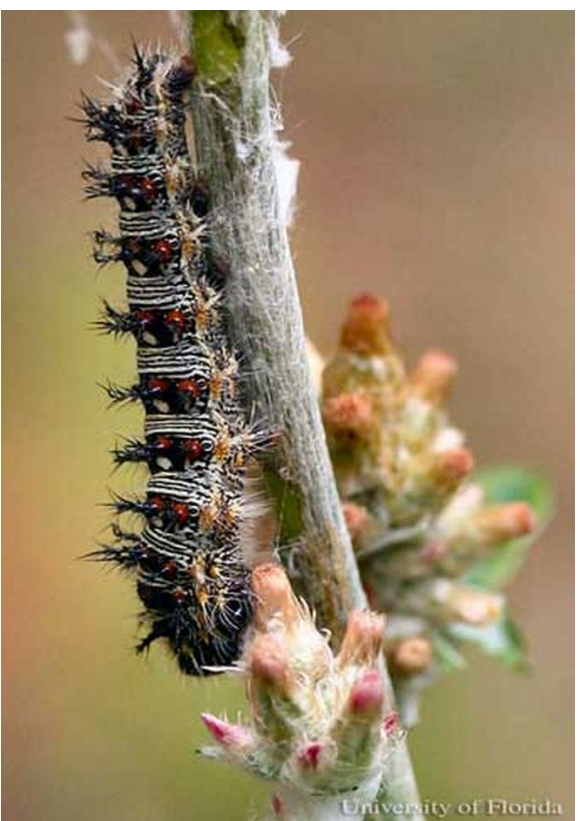

Figure 3. Larva of the American lady, Vanessa virginiensis (Drury). Some larvae are primarily yellow with thin black transverse lines on the anterior and posterior margins of the segments and a narrow transverse black band in the middle of each segment. Credits: Don Hall, University of Florida

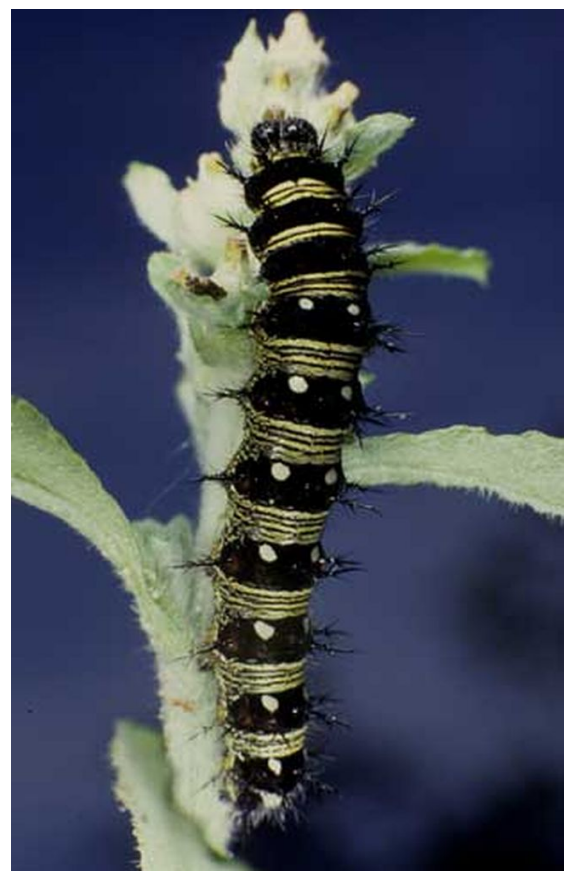

Figure 4. Larva of the American lady, Vanessa virginiensis (Drury). In some larvae, the median black band is much wider so that the larvae appear to be black with narrow yellow lines. Credits: Jerry Butler, University of Florida

Pupae: Pupae are approximately 0.75 inches in length. They may be either greenish with purple markings or gray with dark markings. They hang 
vertically, attached by the terminal end to a small silk pad by the cremaster.

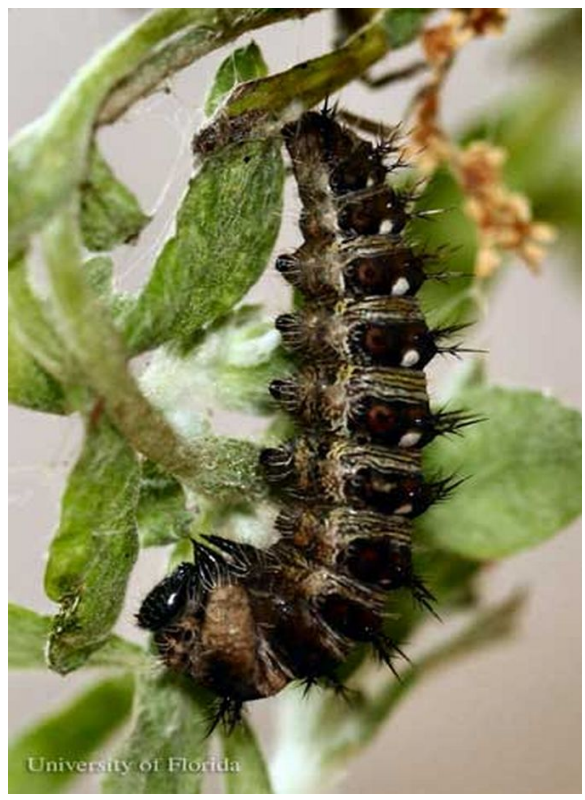

Figure 5. American lady, Vanessa virginiensis (Drury), larva attached to silk pad in typical pre-pupation "J" shape. Credits: Don Hall, University of Florida

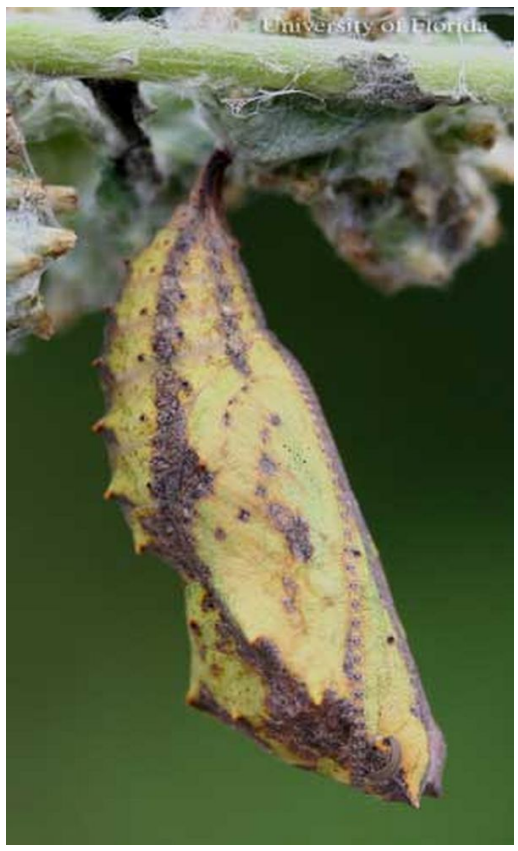

Figure 6. Green pupa of American lady, Vanessa virginiensis (Drury). Credits: Don Hall, University of Florida

\section{Life Cycle and Biology}

There are multiple generations per year in Florida, but they are most common in the spring. Adults and larvae are found in a variety of habitats including uplands, sandhills, flatwoods, lawns, and

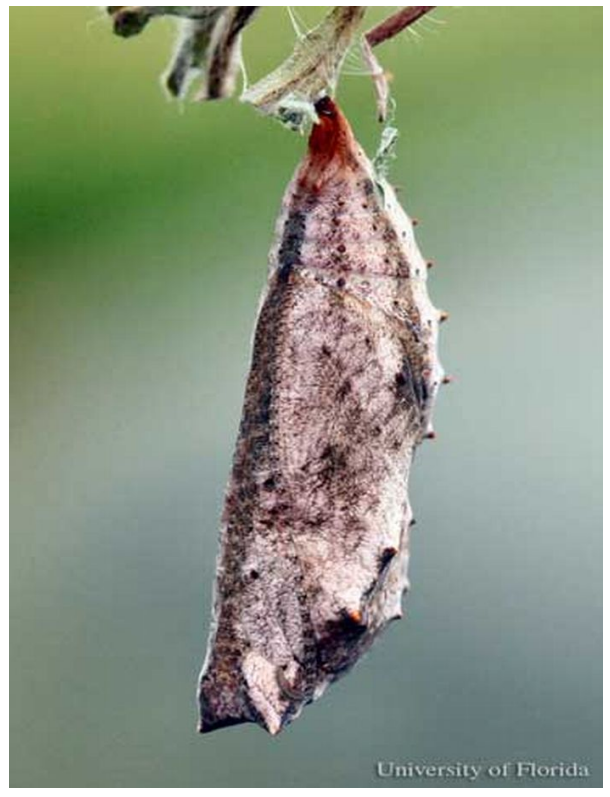

Figure 7. Gray pupa of American lady, Vanessa virginiensis (Drury). Credits: Don Hall, University of Florida

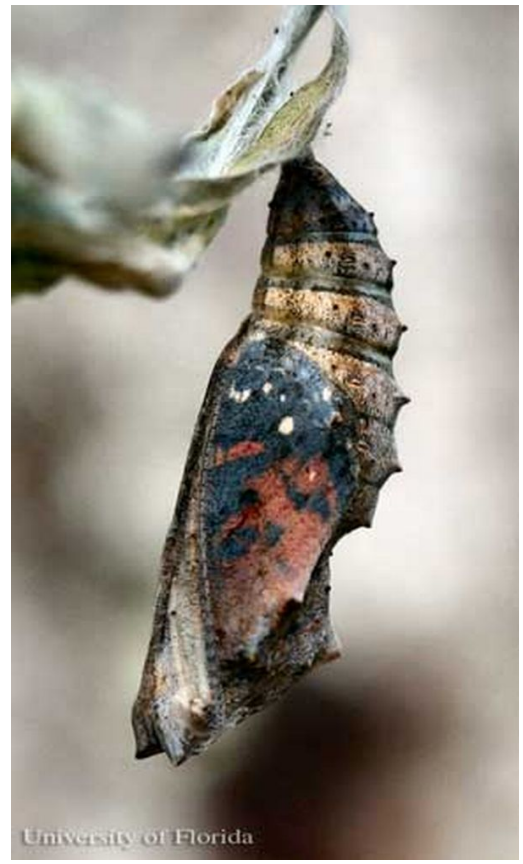

Figure 8. Pupa of American lady, Vanessa virginiensis (Drury), immediately before adult emergence. Credits: Don Hall, University of Florida

weedy areas. Eggs are laid on the upper surface of leaves of the host plants. Larvae make nests at the tops of host plants by silking together leaves and chaff at the tips of the flower stalks where they hide during the daytime and come out at night and on overcast days to feed. 


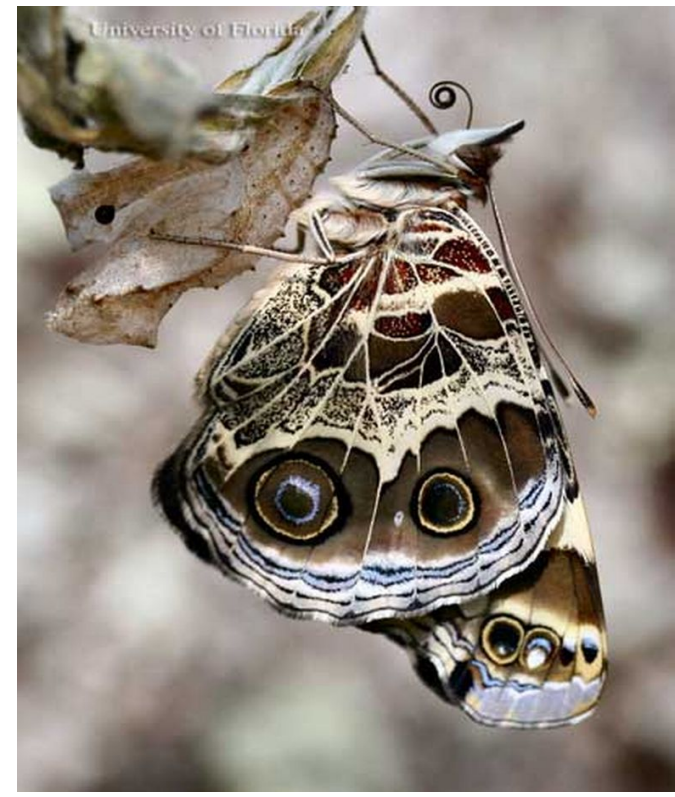

Figure 9. Newly emerged adult American lady, Vanessa virginiensis (Drury), after joining halves of proboscis. Credits: Don Hall, University of Florida

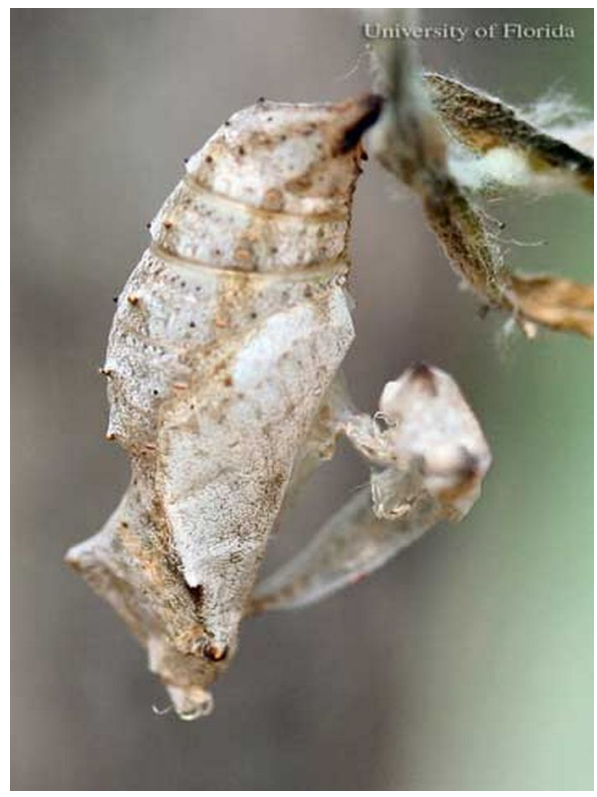

Figure 10. Old pupal skin of a recently emerged adult American lady, Vanessa virginiensis (Drury). Credits: Don Hall, University of Florida

Adults overwinter in the southern U.S. and repopulate more northern areas each spring. The northern limit of overwintering is unknown. Walker (2001) reported that in north central Florida, American ladies migrate northward during the spring, but there is no significant southward migration in the fall.

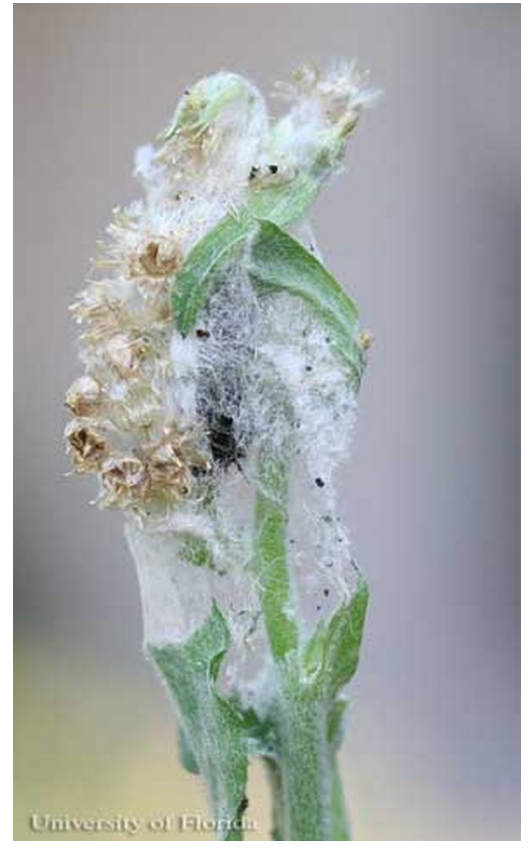

Figure 11. American lady, Vanessa virginiensis (Drury), larval nest on Pennsylvania everlasting, Gamochaeta pensylvanica (Willd.) Cabrera, also known as Pennsylvania cudweed. Credits: Don Hall, University of Florida

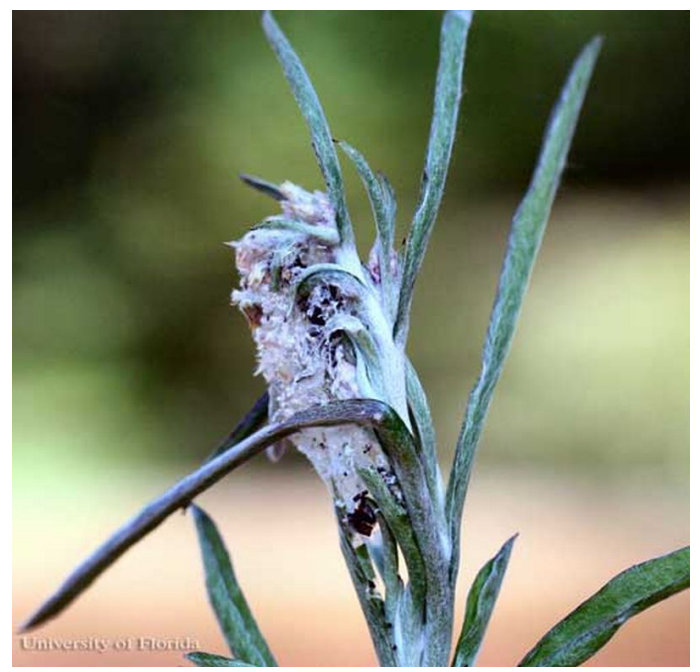

Figure 12. American lady, Vanessa virginiensis (Drury), larval nest on Caribbean purple everlasting, Gamochaeta antillana (Urb.) Anderb., also known as delicate everlasting. Credits: Don Hall, University of Florida

Adults prefer floral nectar but also feed on sap, fermenting fruit, and mud (Allen 1997, Glassberg et al. 2000, Opler and Krizek 1984, Scott 1986).

\section{Hosts}

Preferred plant hosts for larvae are "everlasting" or "cudweed" herbs and their close relatives in the aster family (Asteraceae). Common hosts in Florida are: 
- Pennsylvania everlasting, Gamochaeta pensylvanica (Willd.) Cabrera, also known as Pennsylvania cudweed

- spoonleaf purple everlasting, Gamochaeta purpurea (L.) Cabrera, also known as spoonleaf cudweed

- Caribbean purple everlasting, Gamochaeta antillana (Urb.) Anderb., also known as delicate everlasting

- sweet everlasting, Pseudognaphalium obtusifolium (L.) Hilliard \& B.L.Burtt, also known as rabbit tobacco

These species were formerly placed in the genus Gnaphalium (Wunderlin and Hansen 2003).

Gamochaeta antillana has long been misidentified as Gamochaeta falcata (Lamarck) Cabrera, which is a South American species that does not occur in the United States (eFloras.org Undated_a). For identification keys and characteristics of the Gamochaeta everlastings, see Wunderlin and Hansen (2003) and eFloras.org (Undated_b).

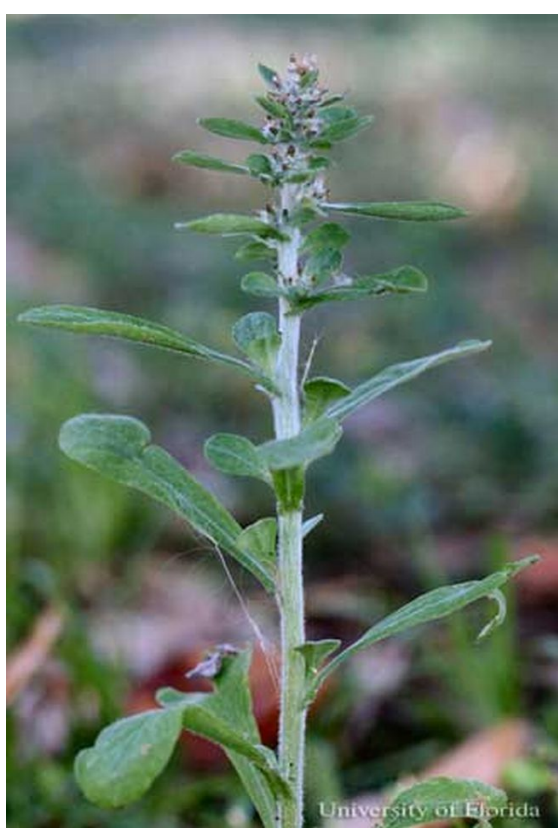

Figure 13. Pennsylvania everlasting, Gamochaeta pensylvanica (Willd.) Cabrera, also known as Pennsylvania cudweed, is a host of the American lady, Vanessa virginiensis (Drury). Credits: Don Hall, University of Florida

In more northern areas, pearly everlasting, Anaphalis margaritacea (Linnaeus) Bentham \& Hooker, and pussytoes, Antennaria spp., are also

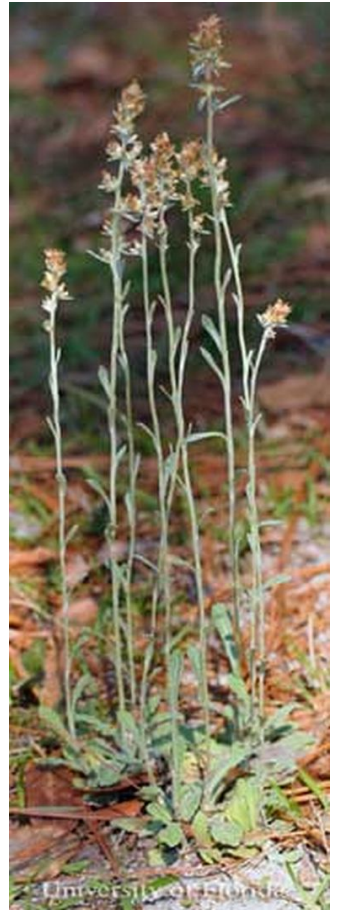

Figure 14. Spoonleaf purple everlasting, Gamochaeta purpurea (L.) Cabrera, also known as spoonleaf cudweed, is a host of the American lady, Vanessa virginiensis (Drury). Credits: Don Hall, University of Florida

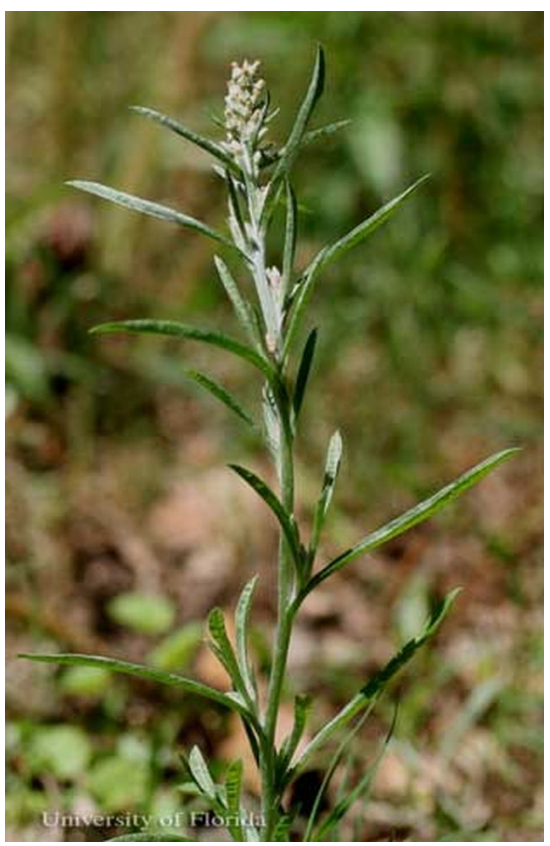

Figure 15. Caribbean purple everlasting, Gamochaeta antillana (Urb.) Anderb., also known as delicate everlasting, is a host of the American lady, Vanessa virginiensis (Drury). Credits: Don Hall, University of Florida

commonly used as larval hosts (Opler and Krizek 1984, Scott 1986). 


\section{Selected References}

- Cech R, Tudor G. 2005. Butterflies of the East Coast: An Observer's Guide. Princeton University Press. Princeton, New Jersey. 345 pp.

- Daniels JC. 2000. Butterflies 1: Butterflies of the Southeast. UF/IFAS. Card Set. SP 273.

- Daniels JC. 2003. Butterflies of Florida: Field Guide. Adventure Publications, Inc. Cambridge, Minnesota. 256 pp.

- eFloras.org. (Undated_a). Gamochaeta antillana (Urban) Anderberg, Opera Bot. 104: 157. 1991. Flora of North America. http://efloras.org/ florataxon.aspx?flora_id=1\&taxon_id=25006679 1 (5 May 2009).

- eFloras.org. (Undated_b). Gamochaeta Weddell, Chlor. Andina. 1: 151. 1856. Flora of North America. http://efloras.org/ florataxon.aspx?flora_id=1\&taxon_id=113220 (5 May 2009).

- Miller JY, ed. 1992. The Common Names of North American Butterflies. Smithsonian Institution Press. Washington, D.C. 177 pp.

- Minno MC, Butler JF, Hall DW. 2005. Florida Butterfly Caterpillars and their Host Plants. University Press of Florida. Gainesville, Florida. $341 \mathrm{pp}$.

- NABA. (September 2004). Checklist of North American Butterflies Occurring North of Mexico. North American Butterfly Association. http://www.naba.org/pubs/enames2.html (5 May 2009).

- Opler PA, Krizek GO. 1984. Butterflies East of the Great Plains. The Johns Hopkins University Press. Baltimore, Maryland. 294 pp.

- Scott JA. 1986. The Butterflies of North America: A Natural History and Field Guide. Stanford University Press. Stanford, California. $583 \mathrm{pp}$.
- Walker TJ. 2001. Butterfly migrations in Florida: seasonal patterns and long-term changes. Environmental Entomology 30: 1052-1060.

-Wunderlin RP, Hansen BF. 2003. Guide to the Vascular Plants of Florida. 2nd ed. University Press of Florida. Gainesville, Florida. 787 pp.

-Wunderlin RP, Hansen BF. (2008). Atlas of Florida Vascular Plants. Institute for Systematic Botany. http://www.plantatlas.usf.edu/ (1 April 2009). 